\title{
FormaÇÃo dE PROFESSORES MEDIADA PELA LINGUAGEM CINEMATOGRÁFICA: FILMES COMO RECURSO PEDAGÓGICO ${ }^{1}$
}

\author{
Camila Streitenberger Coelho, Maria Elaine Neves Azevedo Foganholi ${ }^{\mathrm{H}}$ \\ Sueli Camargo Ferreira ${ }^{\mathrm{HH}}$
}

Palavras-chave: Aluno. Professor. Cotidiano.

INTRODUÇÃO: Este trabalho foi desenvolvido durante o primeiro semestre de 2005, no Instituto de Educação Ismael Coutinho, para a disciplina de Pratica de Ensino I, II e III, ministrada pela professora Sueli Camargo Ferreira. Esta é uma disciplina obrigatória para os alunos do curso de Psicologia que fazem licenciatura. O presente trabalho surgiu a partir das conversas com as professoras de psicologia do Curso Normal, com os alunos e com a supervisora da disciplina, onde podemos constatar as dificuldades desses alunos em desenvolver pensamentos articulados. Tal fato pode ser constatado na dificuldade de escrita e discussões de temas expostos em aula, como afirmou uma professora. Ciente das dificuldades e tendo em vista a construção de um projeto de ensino que pudesse estabelecer um nível de cooperação com essa instância de ensino, procuramos articular tal projeto na perspectiva da complementação das disciplinas de Psicologia da Educação e da Aprendizagem e ao incentivo à expressão oral e escrita dos alunos. O projeto buscou estimular as discussões sobre temas de conteúdos da disciplina de Psicologia da Educação e da Aprendizagem através de filmes que apresentam de forma fictícia a abordagens de temas ligados ao cotidiano escolar.

OBJETIVO: A questão que nos interessou levantar foi acerca da busca de recursos para discussões sobre temas e conteúdos da Disciplina de Psicologia da Educação e da Aprendizagem através dos filmes: "Meu Mestre, Minha Vida” e "Mr. Holland Adorável Professor" que apresentam de forma fictícia a abordagem de temas ligados ao cotidiano escolar. Bem como desenvolver nos alunos a compreensão das temáticas educacionais contidas nos filmes e o aprimoramento da linguagem argumentativa.

METODOLOGIA: Com o propósito de explorar tal questão, fomos buscar esses filmes afim de que eles promovessem o debate sobre a importância do conhecimento para a compreensão da realidade social e estimulassem a formação crítica e reflexiva do professor. Estes filmes foram exibidos cada um em duas sessões seguidas de debates sobre seus pontos principais. Logo após esta atividade foi proposta a construção de um texto contendo uma articulação entre o filme e o debate. Possibilitando assim a efetiva participação dos alunos.

\footnotetext{
${ }^{1}$ Trabalho apresentado na X Semana de Extensão - UFF/2005.

${ }^{H}$ Graduandas do curso de Psicologia - UFF.

${ }^{H H}$ Professora da Faculdade de Educação da UFF

E-mail: cstreitenberger@ig.com.br
} 
RESULTADOS: Nos resultados alcançados observamos que o uso dos filmes como recursos para a sala de aula otimizou a relação ensino-aprendizagem. $\mathrm{O}$ caminho por nós seguido teve a intenção de contribuir para a formação de um professor reflexivo, argumentativo com base em seus conhecimentos de formação e de percepção da realidade.

CONCLUSÃO: Detectamos que o debate sobre assuntos como a realidade do cotidiano escolar e a relação professor-aluno geraram interesse. Possibilitando a participação dos alunos e o compartilhar de idéias que ampliaram a compreensão e articulação desses temas. Sintetizando, o Projeto Cine Clube pretendeu desenvolver um trabalho que permitisse uma postura reflexiva e argumentativa dos alunos do curso de Formação de Professores, sendo assim o projeto avançou mais no sentido de possibilitar uma integração dos conhecimentos didáticos já adquiridos dos alunos com suas vivências extras-muros escolares. 